\title{
PERANAN SITUS SEJARAH DERMAGA SENG HIE BAGI MASYARAKAT KOTA PONTIANAK
}

\author{
F. Sri Dewi Wulandari \\ Program Studi Pendidikan Sejarah IKIP PGRI Pontianak \\ Email: dewiwulandari2402@gmail.com
}

\begin{abstract}
Abstrak
Penelitian ini bertujuan untuk mengetahui sejarah Dermaga Seng Hie, Fungsi Dermaga Seng Hie, dan Eksistensi Dermaga Seng Hie dimasa sekarang. Penelitian ini menggunakan metode Kualitatif. Hasil penelitian menujukan Dermaga Seng Hie sebagai Dermaga tertua yang ada di Kota Pontianak dan didirikan oleh seorang keturunan Cina bernama Tan Sheng Hie sekaligus sebagai pengusaha hasil bumi. Dermaga Seng Hie dijadikan sebagi tempat bongkar muat barang terutama barang komoditi masyarakat. Dermaga seng hie sebagai dermaga pertama di kota pontianak sebagai jalur pendistribusian barang-barang tetap digunakan hingga sekarang.
\end{abstract}

Kata Kunci: Dermaga Seng Hie; situs sejarah; Pontianak;

\begin{abstract}
This study aims to determine the history of the Seng Hie Pier, the function of the Seng Hie Pier, and the existence of the Seng Hie Pier in the present day. This study uses a qualitative method. The results of the study address the Seng Hie Pier as the oldest Pier in the City of Pontianak and was founded by a Chinese descent named Tan Sheng Hie as well as a crop entrepreneur. Seng Hie's dock is used as a loading and unloading place for goods, especially for community commodity goods. Seng hie dock as the first pier in the city of Pontianak as a path for the distribution of goods is still in use today.
\end{abstract}

Keywords: Dermaga Seng Hie; historical site; Pontianak;

\section{PENDAHULUAN}

Kota Pontianak adalah salah satu wilayah yang di lewati oleh garis Katulistiwa. Kota pontianak sendiri berdiri pada tahun 1771 berada di persimpangan Kapuas Kecil dan Sungai Landak. Posisi tersebuat menjadi lokasi strategis karena terletak dijalur perdagangan Internasional dan Nusantara. (Almadani 2013:18) Karena berada pada daerah yang dekat dengan jalur perdagangan internasional masyarakat memanfaatkan daerah tersebut untuk berdagang, maupun melakukan aktivitas lainnya. Ramainya pendatang dari berbagai tempat membuat daerah ini menjadi ramai sebagi pusat dagang yang besar dan membuat Kota Pontianak menjadi daerah yang maju. Perdagangan yang dilakukan di tumpangi juga oleh keberadaan Dermaga yang menjadi tempat persinggahan para pedagang dari luar untuk masuk ke wilayah tersebut untuk menjual barang dagangnya karena seperti yang kita ketahui bahwa perdagangan 
yang dilakukan pada saat itu lebih berpusat pada jalur laut dari pada jalur darat. Hal ini diperkuat dengan sejarah Kota Pontianak yang menitik beratkan sungai sebagai media dalam membantu jalannya semua kegiatan penduduk Kota Pontianak, seperti mandi, sumber air minum, kegiatan jual-beli, serta kegiatan transportasi sungai menggunakn sampan atau kapal.(Br. Gultom 2016:15)

Kota Pontianak memiliki sebuah Dermaga yang dapat menjadi tempat persinggahan dan tempat bongkar muat barang. Dermaga yang dikenal dengan Dermaga tua ini, letaknya di Kota Pontianak dengan nama Dermaga Seng Hie. Keberadaan dan penamaan Dermaga atau Pelabuhan ini tidak terlepas dari nama seorang pengusaha keturunan China Than Seng Hie. Seorang pengusaha hasil bumi setelah sekian lama melakukan kegiatan perdagangan sekitar tahun 1930-an usaha yang dibagunnya mengalami kemunduran, sehingga kemudian ia menjual rumah dan tanahnya ke pihak keuskupan Pontianak, yang di perkirakan pada masa kepemimpinan Uskup Monsieur Pasificus Basch. Sedangkan Dermaga nya sendiri diambil oleh pihak Belanda karena dinilai sebagai tempat yang sangat strategis pada saat itu untuk tempat perniagaan yang sangat maju dan dilanjutkan pada masa kolonialisme Jepang Dermaga ini di manfaatkan untuk membantu mengirim dan menerima persenjataan untuk kebutuhan perang. Hingga pada era Kemerdekaan, Dermaga Seng Hie di ambil dan di miliki oleh pemerintah daerah yang pengelolaan dan kewenagan nya di atur oleh Pemerintah Kota Pontianak melalui Dinas Perhubungan Kota Pontianak.

Dermaga ini terdapat kapal bongkar muat barang dan kapal express yang ditunjukan untuk penumpang jurusan Pontianak-Ketapang maupun distribusi barang ke berbagai daerah. Berdasarkan Rencana Tata Ruang Wilayah Kota Tahun 2013-2033, Dermaga Seng Hie disebutkan sebagai salah satu kawasan strategis dari sisi pengembangan perekonomian Kota Pontianak.(tribun pontianak 2017/10/21) Dan Sampai hari ini pelabuhan Bongkar muat Seng Hie menjadi urat nadi perekonomian masyarakat.(radio republik indonesia 2016/10/21). kisah sejarah dibalik Dermaga ini yang membuat Dermaga Seng Hie menjadi menarik, dan historis ini yang membuat Dermaga ini menjadi istimewa dan dimana nilai 
historis yang tinggi ini mendorong pemerintah Provinsi menetapkan Dermaga Seng Hie sebagai satu cagar budaya yang ada di Kota Pontianak.

\section{METODE}

Metode yang di pakai dalam penelitian ini adalah metode kualitatif, dan melakukan pengumpulan data dengan berbagai literatur, melakukan observasi dan mendeskripsikan tentang materi Dermaga Seng Hie, melakukan beberapa wawancara, mendapatkan beberapa sumber seperti surat kabar, buku-buku yang di dapat kan di perpustakaan maupun jurnal mengenai Dermaga Seng Hie.

\section{HASIL DAN PEMBAHASAN \\ Sejarah Dermaga Seng Hie}

Rumah kediaman Than Seng Hie sendiri, kemudian menjadi $R C$ Vicarage and Chinesechapel. Sekarang menjadi Gereja Gembala Baik, setelah mengalamai pemugaran Besar-besaran pada tahun 1981 Berdasarkan Platte Grond van de Hoofdplaats Pontianak, 1 maret 1934 (peta Pontianak 1934). Kawasan Dermaga Seng Hie ini berada di Kapoeans Weg, terusan dari pasar Besar Weng kedua jalan tersebut kini menjadi jalan sultan Muhammad. Juga tak seberapa jauh dari Voorstraat dan Sulthan Weg (sekarang jalan Tanjung pura) dan Theg Seng Hie weng (sekarang jalan pangsuma).(Asma 2013:73) Dengan keberadaan etnis tionghoa yang mengeluti perdagangan yang dekat dengan pesisir sungai kapuas, ini yang mempengaruhi Dermaga ini menjadi Dermaga yang ramai di gunakan masyarakat.

Dermaga tertua di Kota Pontianak yang di ketahui namanya adalah Dermaga Seng Hie letak dan penamaan pelabuhan ini tidak terlepas dari nama seorang pengusaha keturunan Cina (red: Tionghua) bernama Tan Sheng Hie. Seorang pengusaha dibidang hasil bumi terbesar di pontianak Dermaga Seng Hie didirikan pada masa Hindia Belanda, oleh seorang pengusaha bernama Than Seng Hie selama beberapa dekade Than Seng Hie membuka usaha di daerah Tanjung Pura dan sekitar nya, sekitar tahun 1930-an usaha yang dibagun itu sempat mengalami kemunduran, Tan Seng Hie terpaksa menjual tanah nya kepada pihak 
keuskupan yang diperkirakan pada masa kepemimpinan Uskup Mosieur Pacificus Bosh. Waktu itu Uskup yang memimpin berkewarganegaraan Belanda dan diketahui pada saat itu juga bertepatan dengan keberadaan kolonialisme Belanda sehingga daerah Dermaga diambil alih pihak Belanda, karena mereka menilai bahwa tempat ini adalah tempat yang strategis untuk tempat perniagaan yang sangat maju dapat memberikan keuntungan untuk pihak Belanda dan benar adanya pada masa kepemilikan kolonial Belanda tempat ini menjadi tempat perniagaan yang maju tidak haya itu tempat ini juga digunakan untuk membantu pengiriman barang ke daerah ataupun ke pusat. Pada awal abad ke-20 aktivitas perdagangan Pontianak yang semakin semarak dengan kegiatan ekspor-impor membuat kawasan niaga yang dibagun pemerintah kolonioal semakin membagaun fasilitas utama yang terdapat dalam kawasan ini adalah pelabuhan dengan sarana pendukung nya seperti bangunan dan Dermaga.

Seperti yang di lakukan wawancara dengan Budayawan dan sejarahwan kota Pontianak. Berdasarkan hasil wawancara, Syafarudin Usman MHD mulanya pelabuhan Seng hie adalah sebuah Dermaga niaga milik seorang pengusaha China bernama Thang Seng Hie. Pada masanya dia adalah seorang pengusaha hasil bumi yang sangat sukses "Theng Seng Hie membangun Dermaganya untuk menunjanjang aktivitas perdagangan yang menggunakan banyak, sehingga dermaga ini berkembang dan perlahan menjadi kawasan kegiatan perniagaan" katanya dia menuturkan tahun 1930 Kolonial Belanda mengambil alih Dermaga Seng Hie karena dinilai sebagai transportasi yang kreatif secara perekonomian. Dimasa kepemilikan Seng Hie oleh kolonial Belanda Dermaga menjadi semakin ramai karena letak nya yang berdekatan dengan Selat Malaka maupun laut Cina Selatan Pontianak menjadi bandar perdagangan yang sibuk saat itu menjadi Dermaga Singgah bagi Kapal-kapal yang berlayar dari dalam atau luar kota seperti Jakarta, Riau, Makasar, Banjarmasin sebelum ke Singapura.

\section{Fungsi Tan Seng Hie}

Seng Hie adalah sebuah Dermga Tua yang ada di kota Pontianak dan tempat ini di fungsikan untuk melakuakan kegiatan yang berkaitan dengan 
perdagangan dan perekonomian masyarakat maupun tempat wisata. Dermaga Seng Hie dikenal sebagai salah satu pangkalan niaga yang pertama yang ada di Pontianak pangkalan niaga yang di maksud adalah pangkalan yang menjadi tempat perdagangan yang pertama di Kota Pontianak. Dalam perdagangan yang ada, Dermaga ini di fungsikan untuk mengantar atau membawa barang dari daerah untuk dibawa keluar maupun masuk ke Kota Pontianak dari berbagai barang komoditi hasil bumi masyarakat diantaranya seperti ikan asin, karet, tengkawang dan yang lain nya sedangkan dari luar akan membawa barang dagangan nya untuk di bawa masuk ke daerah Kota Pontianak. Dermaga Seng Hie terletak dijalan Sultan Muhammad, kelurahan Benua Melayu Laut, kecamatan Pontianak Selatan Kota Pontianak. Posisinya berada di tepi sungai kapuas, sungai terpanjang di bumi Katulistiwa diseberang sungai istana Qadariah dan mesjid Jami dua bangunan bersejarah Kesultanan Pontianak menjadi tempat bongkar muat barang dikarenakan penggunaan dengan melalui jalur air atau transportasi laut adalah tranportasi yang menjadi tempat pemasuk barang yang sangat besar karena kemudahan untuk mengakses jalurnya di bandingkan menggunakan transportasi darat masih sangat minim atau masih sangat terbatas untuk di gunakan sebagai jalur perdagangan yang penting. Menjadi Dermaga satu satunya di Kota Pontianak membuat tempat ini sebagai pusat dari kegiatan perekonomian masyarakat Kota Pontianak.

Untuk sekarang Dermaga Seng Hie juga masih di fugsikan sebagai pelabuhan bongkar muat barang, penyeberangan maupun pelayaran express yang terletak dijalan Sultan Muhammad, kelurahan Benua Laut, Kecamatan Pontianak Selatan Kota Pontianak Kalimantan Barat posisinya berada di tepi sungai kapuas, sungai terpanjang di Bumi Katulistiwa Diseberang sungai, istana Qadariah dan mesjid Jami berdiri kokoh, sebagai dua cagar budaya warisan Kesultanan Pontianak. Sungai dan penyeberangan yang ada pada daerah Seng Hie regulasinya mengacu kepada Peraturan Menteri Perhubungan, Keputusan Menteri Perhubungan dan Pengaturan Walikota yang mengatur aktivitas Pelabuhan dalam Kota Pontianak serta Peraturan yang berkaitan dengan angkutan sungai dan penyeberanagan. Hingga kini Dermaga Seng Hie menjadi Pelabuahn bongkar 
muat barang maupun tempat penyeberangan Dermaga ini memang lebih bayak melayani bongkar muat kapal-kapal dengan rute ke pelabuhan rakyat yang biasa dikenal sebagai Dermaga pedalaman atau pelabuhan pedalaman dengan rute misalnya sepanjang Kapuas kemudian ke berbagai Kabupaten yang ada dalam wilayah Kalimantan Barat seperti kabupaten Ketapang.

Sampai sekarang fungsi dari Dermaga ini juga sebagai urat nadi perekonomian masyarakat Karena lewat dermaga ini pengirim berbagai bahan kebutuhan pokok masyarakat, mulai ke daerah seperti Kayong Utara, Ketapang dan daerah lain nya. Dermaga ini yang menjadi tempat persinggahan para kapal dan sebagai tempat bongkar muat barang yang akan dibawa, barang-barang yang di angkut seperti beras, minyak, sembako maupun lain nya. Di Dermaga Terdapat kapal bongkar muat standar, terdapat juga kapal muatan dan kapal expres yang di tunjukan untuk penumpang jurusan Pontianak-Ketapang. Kawasan Seng Hie juga di katakan sebagai salah satu kawasan strategis dari sisi pengembagan perekonomian Kota Pontianak.

\section{Eksistensi Dermaga Seng Hie untuk sekarang}

Eksistensi Dermaga Seng Hie dimulai dari kepemilikan yang pertama yaitu saudagar Tionghoa yaitu Than Seng Hie yang mana Dermaga ini di gunakan sebagai tempat bongkar muat hasil bumi dan barang komoditi yang ada di Kota Pontianak namun setelah mengalami kemerosotan dalam usahanya pengambilan alih kepemilikian Dermaga ini dilanjutkan dengan keberadaan kolonial Belanda yang berada di kota Pontianak yang mana menguasai Dermaga tersebut dan di gunakan sebagai jalur untuk membawa barang-barang maupun membongkar muat barang hasil bumi. Kemudian masuk pada era kolonial Jepang daerah ini digunakan juga untuk menopang pembawaan barang untuk keperluan perang dan di lanjutkan dengan masa era kemerdekaan, Dermaga ini diambil alih oleh pemerintahan dan sampai sekarang, hingga pemerintah menetapakan atau menjadikan Dermaga ini sebagai daerah cagar budaya penetapan tempat ini sebagai cagar budaya dikarenakan bukan semata-mata daerahnya yang berada sangat strategis di dekat sungai kapuas atau pasar besar tapi karena memang 
historis nya yang unik dan menjadi salah satu tempat bersejarah bagi Kota Pontianak.

Ada beberapa fase dari kepemilikan saudagar Seng Hie untuk bongkar hasil bumi nya kemudian masuk fase kolonial Belanda hingga Jepang seterusnya sampai setelah kemerdekaan Seng Hie menjadi salah satu urat nadi distribusi barang dan jasa di Kota Pontiak. Dermaga Seng Hie yang di gunakan dari awal Kolonialisme hingga kemerdekaan tetap memberikan peran nya untuk membantu penyaluran dan pengiriman barang semacam sembako, kebutuahan pokok yang di distribusi kan ke daerah-daerah masih menjadi jalur distribusi barang yang diangkut ke berbagai daerah kabupaten kota seperti Ketapang, Sukadana, Kayong kemudian ke Telok Batang bahkan ada yang samapi melintas ke teluk Sunda Kelapa Jakarta, Natuna. Menggunakan kapal-kapal rakyat yang ada maupun kapal kargo dulu komoditas yang di angkut dari dan ke pelabuhan Seng Hie dulu tempat mendistribusi ikan namun sekarang tidak namun sekarang lebih ke bahan-bahan pokok seperti sembako, pupuk, semen bahkan tiang listrik untuk daerah-daerah pedalaman untuk sandar dan tambat kapal ada juga jurusan Semarang semua mengangkut barang-barang komoditas seperti pupuk, semen, beras, tepung, minyak, dan bbm.

Pengelolaan Dermga Seng Hie sendiri diambil alih oleh pemerintah Kota Pontianak, pembenahan pun terus dilakukan apa lagi dengan kemajuan Kota pontianak dan Kalimantan Barat yang signifikan, juga dapat berpengaruh terhadap peningkatan aktifitas bongkar muat di pangkalan Seng Hie. Luas Dermaga yang dahulunya hanya beberapa meter, kini telah bertambah 1,8 Ha. Dermaga Seng Hie yang dulu nya hanya merupakan sebuah pangkalan berstruktur kayu atau Dermaga kayu, kemudian dibagun kembali dan direnovasi oleh pemerintah kota tahun 200an dengan struktur beton. "sekarang sudah lebih luas dan lebih besar yang struktur bagunan nya dari kayu sekarang sudah beton sehingga bisa disinggahi, yang awal nya bersifat pangkalan kapal-kapal rakyat, sekarang panjang dan lebar Dermaga sudah jauh lebih bertambah. Kemudian struktur konstruksi juga sudah beton sehingga bisa di singgahi dengan kapal-kapal niaga ukuran sedang dan juga kapal penumpang seperti express tujuan Pontianak-Ketapang, kemudian kapal kargo 
tujuan Pontianak-Ketapang dan kapal pinisi tujuan Pontiank-Semarang dan kapal pinisi tujuan Pontianak-Jakarta" jelas Alfri

Untuk sekarang ini pelabuhan Seng Hie menjadi pelabuhan Bongkar muat barang juga pelabuhan Seng Hie ditetapkan sebagai cagar budaya oleh dinas Pariwisata Provinsi Kalimanatan Barat. Dan Dermaga ini sendiri dimasukan dalam tatanan perencanaan pembagunan Kota oleh pemerintah Kota Pontianak dan untuk angkut orang sendiri seperti Express sudah mulai tidak digunakan terlinasi oleh zaman, awal tahun 2018 expres tidak lagi beroprasi karena persaianagn antara jalaur lain nya seperti pesatnya dan mudah nya pengaksesan jalur darat dan udara yang mana biaya sama juga denagn penggunaan expres dan jarak tempuh yang dilalaui lebih cepat dari pada menggunakan expres ditambah biaya diangap sama saja dan untuk meng oprasikan expres ini sendiri memakan biaya yang cukup besar, sedangkan peminat mulai berkurang sehingga diangap tidak bisa mengembalikan modal untuk keberangkatan. Jadi Pelabuhan ini lebih digunakan untuk pengantaran barang-barang seperti bahan pokok, dan alat-alat keperluan masyarakat.

Berikut adalah salah satu suasana yang ada pada Dermaga Seng Hie untuk sekarang. Ini adalah salah satu gambar yang mana masih di orasikan nya Dermaga ini dan memiliki beberapa kapal yang masih aktif berlayar atau di oprasikan.

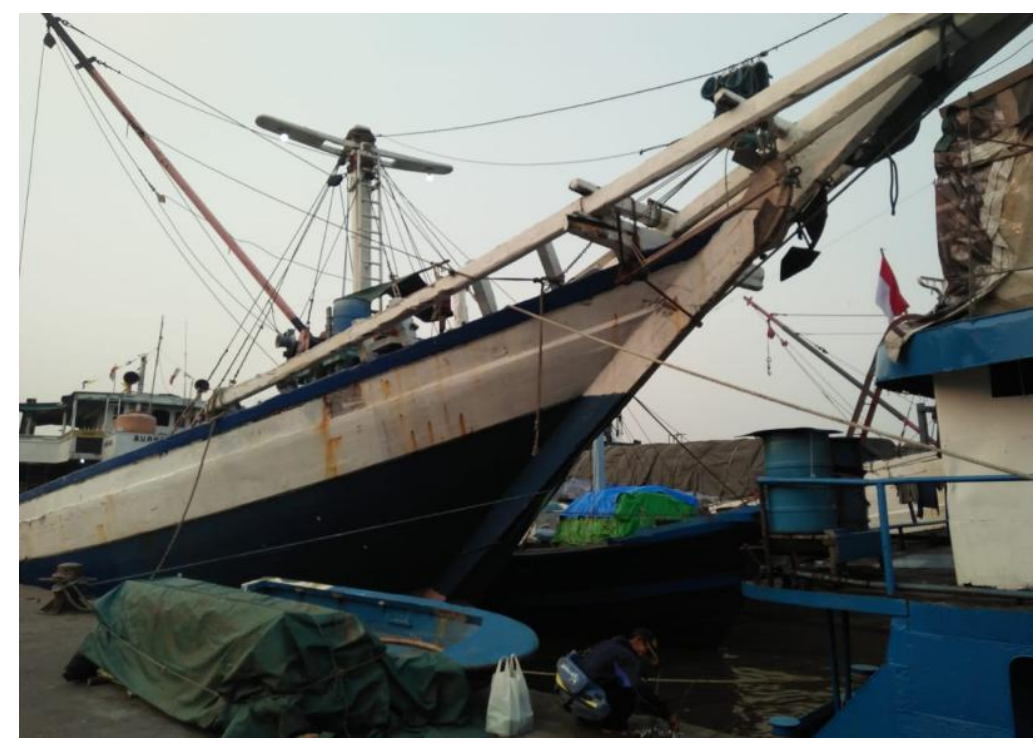

Gambar 1. Suasana Dermaga Seng Hie 


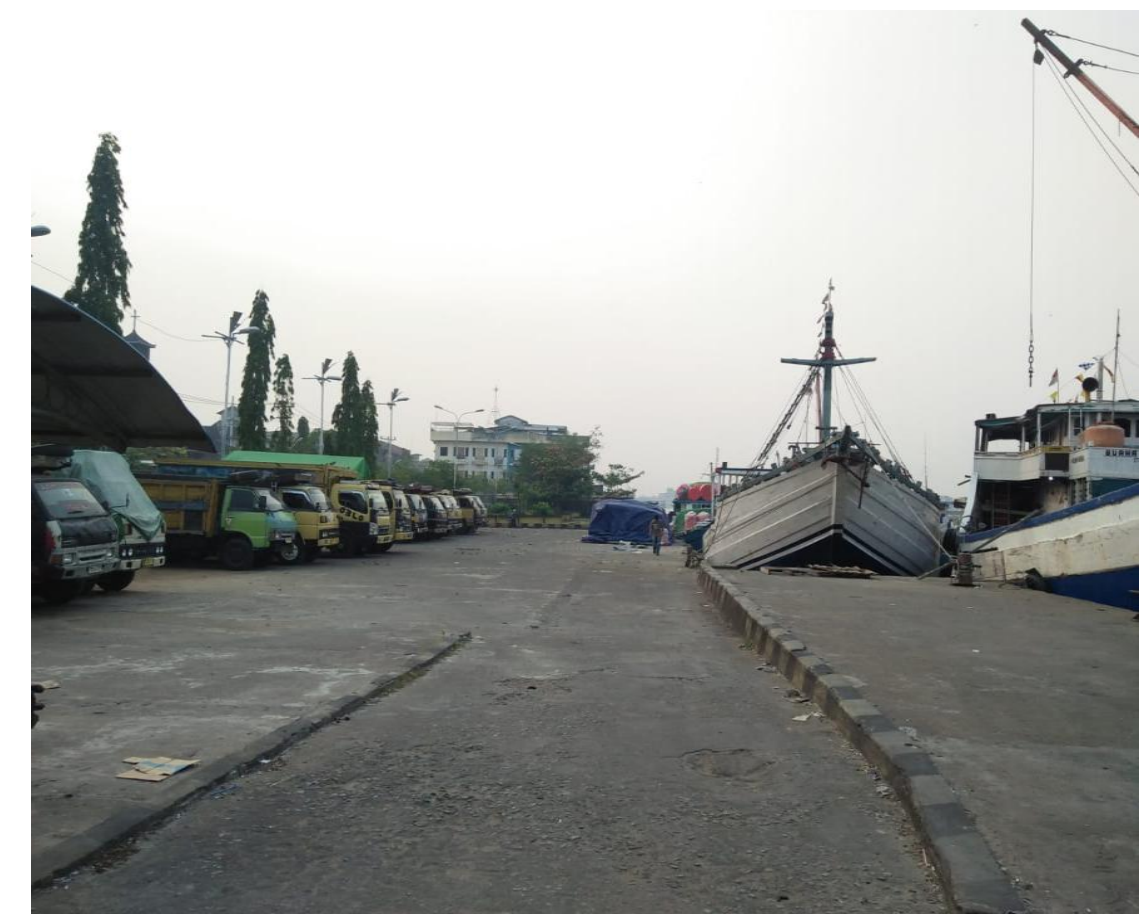

Gambar 2. Kapal-kapal yang ada di Pelabuhan Seng Hie

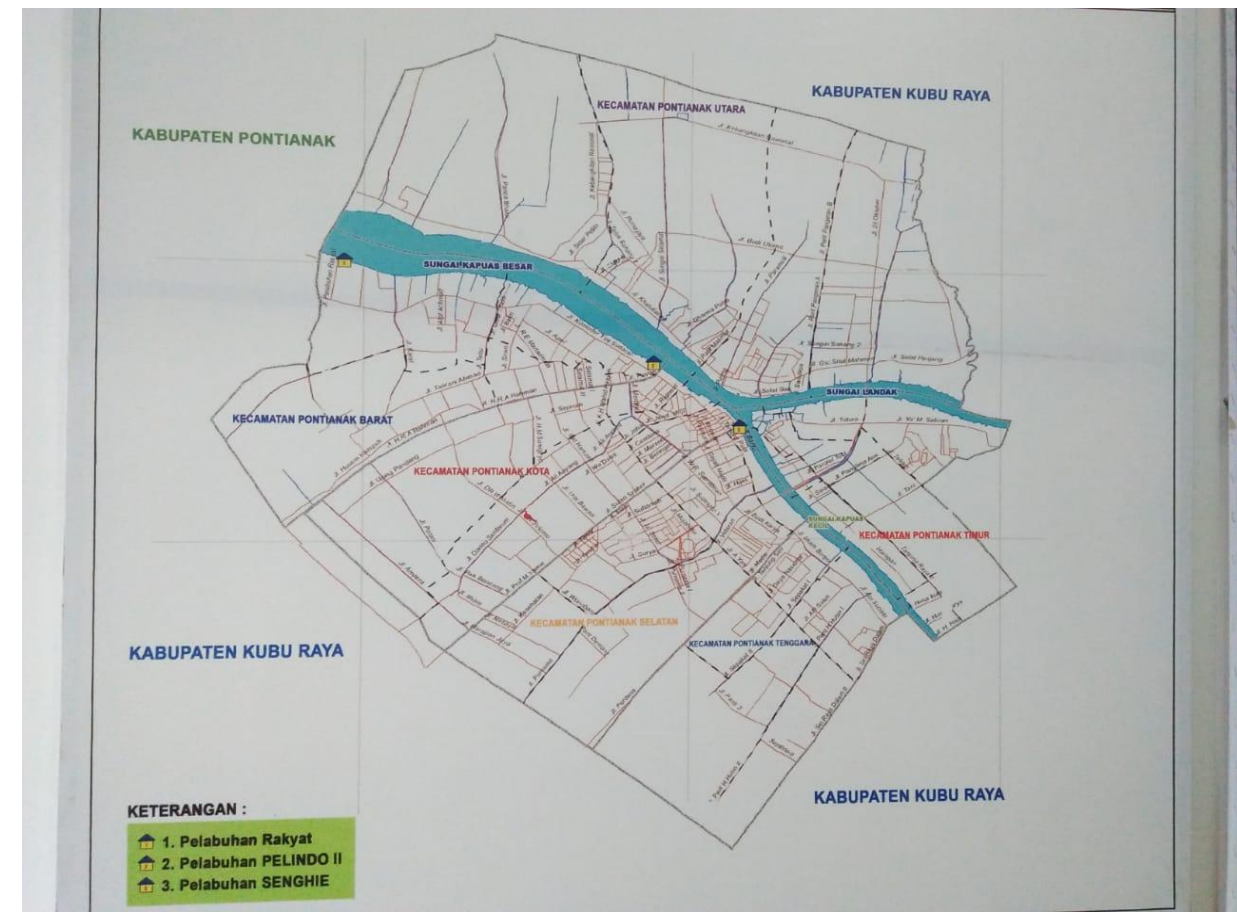

Gambar 3. Peta pelabuhan kota Pontianak 
Dermaga Seng Hie dijadikan cagar budaya karena sejarah nya yang membuat dinas menetapkan pangkalan ini menjadi cagar budaya yang ada di Kota Pontinak. Dermaga Seng Hie sekarang di atur oleh pemerintah daerah Aktivitas pangkalan nya pun semakin ramai menurut Alfri ST.MT, kepala Angkutan Perairan Dinas Perhubungan Komunikasi dan Informatika/ Dishubkominfo Kota pontianak. Jika dilihat secara geografis, Pontianak berada pada posisi yang cukup strategis, karena berada di rute pelayara yang berdekatan dengan wilayah seperti singapura, dekat dengan Selat Malaka serta dengan laut Cina Selatan menjadikan Pontianak sebagai salah satu jalur perdagangan pada masa penjajahan Belanda di tambah Dermaga Seng Hie sebagai bandar perdagangan pelabuhan singgah bagi kapal-kapal yang berlayar dari Maksar, Surabaya dan Banjarmasin

Sesuai dengan RTRW Kota Pontianak tahun 2013-2033 dan rencana Pembangunan Jangka Menengah tahun 2015-2019 Dermaga Seng Hie menjadi cagar budaya yang di lindungi dan pada tahun 2005 di tetapkan Dermaga Seng Hie yang awalnya dikenal sebagai pangkalan niaga pertama di Kalimanatan Barat khususnya Kota Pontianak menjadi salah satu cagar Wisata. Dikarena Seng Hie menjadi pangkal pertama niaga membuat pemerintah memetapkan tempat ini menjadi cagar budaya di darerah Kota Pontinak, dijadikan cagar budaya karna memilki historis yang berpengaruh terhadap wilayah itu sendiri jadi pemerintah mengambil kebijakan dengan menjadikan nya sebagai tempat cagar budaya yang harus di lestarikan dan harus dikenal oleh orang.

Berikut adalah salah satu tugu yang dibuat pemerintah untuk menandakan penetapan nya tempat ini sebagai cagar budaya yang ada di Kota Pontianak dan menadakan Dermaga ini menjadi Dermaga niaga pertama di Kota Pontianak oleh Dinas Pariwisata. 


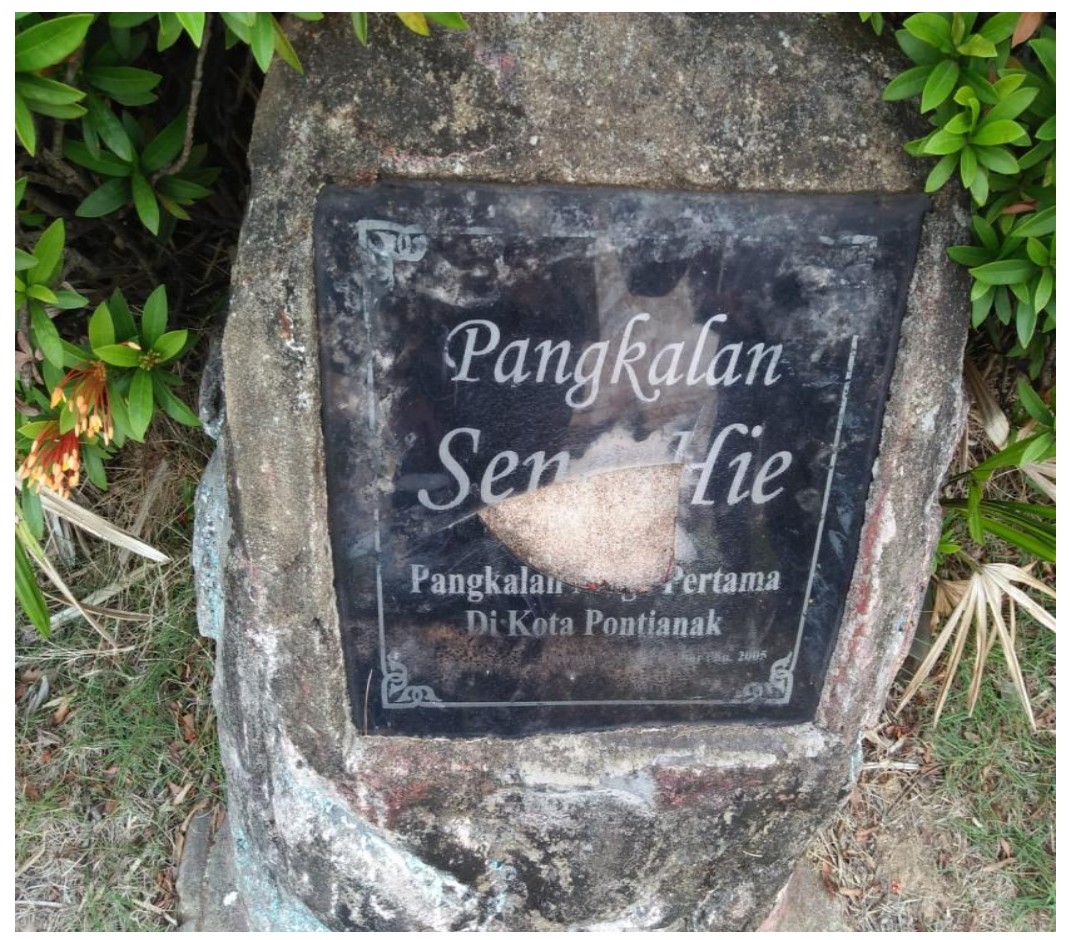

Gambar 4. Tugu Pangkalan Seng Hie

Berikut adalah salah satu peraturan daerah tentang Tata Ruang Wilayah Kota Pontianak yang berkaitan dengan angkutan sungai dan penyeberangan yang berkaitan dengan Dermaga Seng Hie sebagai berikut:

Paragraf 1

Sistem Jaringan Transportasi Darat

\section{Pasal 9}

(1) Sistem jarinagn transportasi darat sebagai mana di maksudkan dalam pasal 8

ayat (2) huruf meliputi: pada bagian,

b. Jaringan Angkutan Sungai dan Penyeberangan

(11) Sistem Jaringan Sungai dan Penyeberangan sebagai mana dimaksud pada ayat (1) huruf $b$, meliputi: pada bagian,

b. Lintas Penyeberangan, meliputi:

1. penyeberangan Bardan Hadi (Alun Kapuas)- Siantan Kecamatan

Pontianak Selatan

2. penyeberangan Seng Hie kampung Beting, kecamatan pontianak selatan

c. Pelabuhan Sungai, meliputi:

1. pelabuhan Seng Hie di Kecamatan Pontiank Selatan dan

2. Pelabuhan Kapuas Indah di Kecamatan Pontianak Kota 


\section{SIMPULAN}

Dermaga Seng Hie adalah salah satu Dermaga yang tertua di kota Pontianak dari fase kepemilikan Thang Seng Hie, kolonial Belanda, Kolonial Jepang sampai era Reformasi dan samapai sekarang memilki jalan cerita atau historis yang sanagat unik dan dimana letak dari Dermaga ini sangatlah strategis dilewati jalur internasonal yang menghubungakn beberapa daerah yang ada dan sebagai pendistribusian barang, jasa maupun orang Dermaga Seng Hie ini lebih dikenal sebagai tempat bongkar muat barang dan tempat mengantar baranag ke seluruh wilah dan mensuplay barang barang-barang kebutuhan pokok. Sekarang ini Dermaga Seng Hie menjadi urat nadi perekonomian yang ada di Kota Pontianak, Dermaga ini ditetapkan sebagai salah satu Cagar Budaya yang ada di Kota Pontianak di kelola oleh dinas perhubungan dan penyebrangan di kota pontianak.

\section{DAFTAR PUSTAKA}

Asma, Ahmad dz. 2013. Pontianak Heritage Dan Beberapa yang Berciri Khas ,cet 1 . Pontianak : Literer Khatulistiwa.

Almadani, M. Ridha . Gunawan, Ivan. 2013. "Identifikasi Bangunan Cagar Budaya Bangunan Kuning Agung, Seng Hie, Pontianak”, Jurnal Universitas Tanjungpura, 18.

Listiana, Dana. 2009. Ibukota Pontianak 1779-1942, Lahir dan Berkembangnya Sebuah Kota Kolonial. Pontianak. Balai Pelestarian Sejarah dan Nilai Tradisional Pontianak Wilayah Kalimantan.

Br.Gultom, Bontor Jumaylinda. Purnomo,Yudi. Gunawan, Ivan. 2016. "Identifikasi dan Evaluasi Akses Publik dan Open Space di Kawasan Seng Hie Pontianak". SPontiank. Jurnal Universitas Tanjungpura. Vol. 3, no. $1: 15$.

Syafylloh, Muhammad, Wibowo, Basuki. (2016). "Pemanfaatan Benda Cagar Budaya Sebagai Potensi Pariwisata Dan Ekonomi Kreatif Bagi Masyarakat Sekitar Di Kota Pontianak Kalimantan Barat" jurnal Sejarah dan Budaya. Nomor 2, hal 225. 
Boyke Sinurat. 2016. "Sheng Hie,Dari Pangkalanmenuju Pelabuhan". http://m.rri.co.id/vol/post/berita/319664/daerah/sheng-hie-dari-pangkalanmenuju-pelabuhan.html. Radio republik indonesia. di akses pada 15 agustus 2018 jam 15.03.

Claudia Liberani. 2017. "Menilik Sejarah Pelabuhan Seng Hie di kota Pontianak". http://pontianak.tribunnews.com/2017/10/21/menilik-sejarah-pelabuhanSeng-hie-di-kota-pontianak. Tribun pontianak.co.id. Diambil pada 24 juli 2018 jam 09.12 . 